\title{
The Impact of Economic Activity on Global Warming
}

\author{
Alexandru Gribincea \\ Free International University of \\ Moldova
}

\author{
Corina Gribincea \\ University of European Studies of \\ Moldova
}

\author{
Alexandru A. Gribincea \\ State University of Moldova
}

\begin{abstract}
Global problems are the problems that affect the entire population of the Earth and represent advantages and perils to the whole human society. The topicality of the research resides in solving the global problems of humanity in different fields, but all of them test the maturity of the society by changing the mentality and finding common solutions for tackling them. The methods of research are based on the directives regarding the global problems related to the gaps in the economic development in different regions of the Earth, the problem of the environment, the malnutrition, the resources, the energies, the migration, etc. along with these, the following methods were used: the method of comparison, induction, deduction, and forecasting, etc. Changes in people's way of life are often linked to natural cataclysms, climate change, natural disasters (floods, volcanic eruptions), war, political, religious, etc. Currently, climate change implies that the processes and phenomena will be repeated, so that a part of the population will be affected, being forced to migrate or being subject to the action of harmful factors. The displacement of a large number of populations will lead to wars, social and economic problems (food, access to drinking water), politics, and dissatisfaction with other groups. The purpose of the research is to study the impact of human activity and to determine possible ways of overcoming the problems that affect the environment. Research denotes that there are chances to tackle these challenges but it requires the involvement of all government structures and people. The authors' research indicates that a global strategy is needed to reduce the negative effect of human activity on Earth. It is necessary to more actively implement IT, ICT, intelligent devices and technologies in the development of the "green economy".
\end{abstract}

Keywords - human activity, economic development, depletion of resources, $\mathrm{CO} 2$ emission, greenhouse effect, green economy

\section{INTRODUCTION}

The desire to live a better and a more decent life is often accompanied by different risks: cosmic, economic, industrial, agricultural, health, climatic, of natural disasters, human, etc. Crisis is time for saving and increasing efficiency. Companies have recently begun to look more closely at the future and to consider renewable sources. In order to reduce the risks in the global economy and lay the foundations for steady and sustainable economic growth, urgent and concrete political measures and will are needed. The dynamism and inclusiveness of the global economy play an essential role in addressing the ambitious goals of the 2030 Agenda for sustainable development. Policy makers should strive to prevent the increased short-term risks associated with financial problems and the exacerbation of trade disputes, to keep on achieving economic, social and environmental goals as part of further implementation of the long-term development strategy. The risk is the possibility of an unfavorable situation or of an unsuccessful result of production, business or any other activity. Technogenic risks are the risks associated with human activities (for example, environmental pollution). Natural risks are risks independent of human activities (for example, an earthquake). Mixed risks deal with natural phenomena, but related to human activities (for example, a landslide is associated with construction work, warming and environmental pollution, catastrophes and human error). Human life and activity are subject to continuous risk. The risks may be different in nature (fig. 1). The humanity's goal is to study the risk factors and mitigate their consequences.

In recent decades, cosmic, geological and human factors have led to global warming. Thermal pollution is the reason for the creation of thermal islands, the local (artificial) inversion of the temperature above the source, which leads to the development of the microcirculation in the atmosphere, a change of the microclimate and a complication of the pollution transfer mechanism. There are problems in rivers and coastal ocean waters. Such pollution is usually associated with the use of natural water as cooling agents in industrial processes, such as power plants. The water returned to the water bodies by enterprises is warmer than the source and therefore contains less dissolved oxygen. At the same time, environmental warming increases the metabolic rate of inhabitants and, therefore, their demand for oxygen.

Level of scientific development of research theme. The thermal pollution is the reason for the creation of thermal islands, the local (artificial) inversion of the temperature above the source, which leads to the development of the microcirculation of the atmosphere, a change of the microclimate and a complication of the pollution transfer mechanism. Simon Cooper, in 2011, in relation to the UN Climate Change Conference in Durban, wrote that the apparent lack of preparedness for international community action was hardly associated with the few voices of climate skeptics. It would be a great mistake to believe that political decisions, including those related to climate change attitudes, are linked to scientific ideas about this phenomenon [9]. In our opinion, Simon Kuper refers to Daniel Sarewitz's thesis, according to which the political interests and the desire to change on a series of environmental problems from the 1970 's were much stronger than the scientific data available at the time on relevant issues in comparison with what we know about them today [8]. That is why conflicts of political interests at that time should have been discussed in public [13]. "Modest" steps taken by the Kyoto, Rio, and Paris agreements, did not find support in all countries. Moreover, 


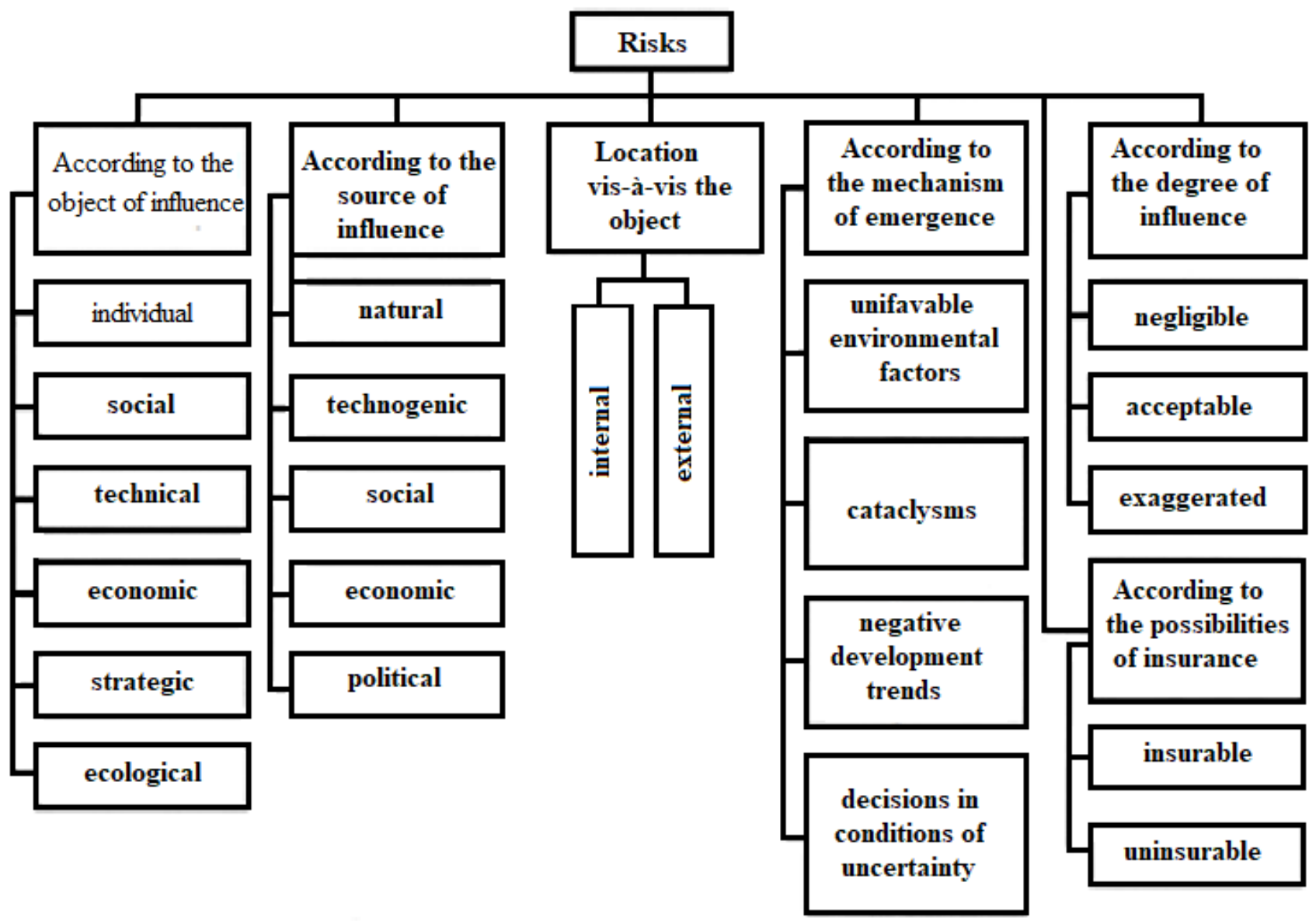

Fig. 1. Classification of Risks in Economic Activity [authors' research based on [6]

the proposed aids are often rejected (Amazon fires, summer 2019).

Simon Cooper emphasized that supporters of climate change theory, determined by human factors, are unlikely to be more numerous than skeptics. A significant factor in global climate inaction is the lack of preparedness in most leaders.

The conceptual basis of the global environmental economy, as an independent field of economic research, has become the problem of internalizing the external effects, comprehensively developed in the works of P. Anderson, O.F. Balatsky, U.Baumol, S.N. Bobylev, A.A. Goluba, K.G. Hoffman, A.A. Gusev, R.Coase, A.Niza, V.N. Ovchinnikov, W.Oates, T.Piers, G.A. Motkin, N.V. Pakhomova, A.Pigu, E.B. Strukova, K.Turner, T.Tytenberg, A.Freeman and others, recognizing the efficiency of market regulators in the process of using natural resources. Supporters of this theory stress the need for strict management and control of the state's environmental management process. The principles of the unity of social-economic and natural development, optimal creation and rational management of sustainable social and ecological systems were studied by V.I. Vernadsky within the concept of noosphere, further developed in the works of A.Humbolt, K. Ritter, T.D. Chardin, E.Leroy, N.V.Timofeev-Resovsky, J. Hasley, Yu.G Saushkina, A.V.Yablokova.

In addition to the aforementioned, it must be acknowledged that, despite the relentless attention of local and foreign researchers on the aspect of the harmonious correlation between economic development and the ecological consequences of international relations, the state of the environment (as a whole) does not change for the better. There are a number of problems regarding the mechanism for making and implementing collective decisions regarding environmental safety, the specificity of its implementation in the economy of many countries leaves much be desired (for economic reasons), as well as the subsequent reform directions to ensure the sustainable progressive development of the society.

The purpose of the research is to study the relations between the continuum of international economic relations, society and environment in its development, based on the findings and the results of the practical recommendations regarding the formation of a harmonious system of sustainable development.

The object of the research is the relations between the countries and the economic and environmental activities in the context of global transformations. The object of the study is marked by the forms of implementation of the environmental and economic relations, as well as the modalities of interaction between different public and private structures in conditions of progress.

The theoretical and methodological basis of the research are the fundamental provisions of the modern economic theory, the works by the representatives of the schools and of the national and foreign economic directions. In the course of the research, we studied UN proposals, legislative acts and normative documents that reflect the 
forms and methods of regulating social and economic processes and contain concepts for reforming the system of economic and environmental management in the economic space. The sources of information were the materials from statistical and regional agencies, provided by international and domestic public organizations.

Results and analysis. Sometimes the figures hide the instability and a comeback in many developing countries and unequal economic progress around the world. Although economic prospects around the world have improved over the last two years (Fig. 2), per capita income is declining in many big developing countries. According to the forecasts, in 2019, an additional decrease or a rate of growth of per capita income will be observed in the central, southern and western parts of Africa, West Asia, Latin America and the Caribbean - regions with almost a quarter of the population of the world that lives in extreme poverty.

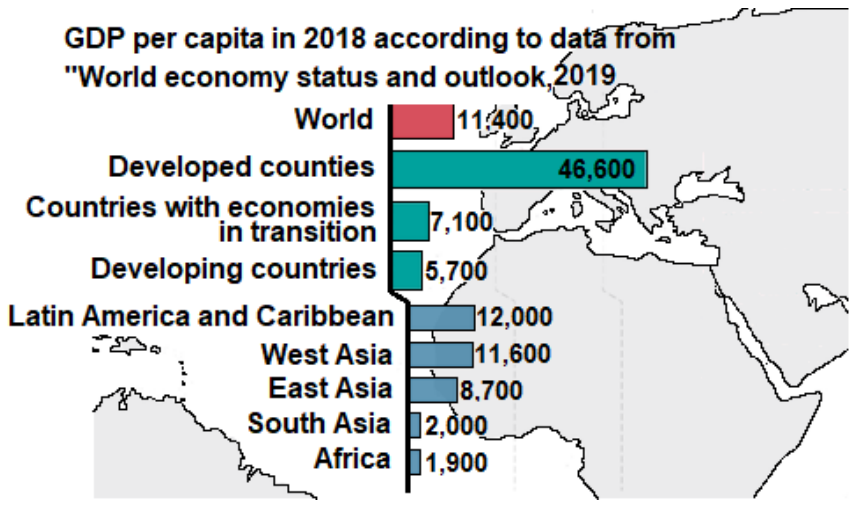

Fig. 2 The Development of the Groups of Countries according to the Economic Level [11]

Human activity, economic and industrial development and other factors favor the warming and pollution of the environment. So far, scientists with $100 \%$ certainty cannot say that these are the causes of climate change. Currently, regarding the causes of global warming, many theories and assumptions persist. We can highlight some, more important of them:

Hypothesis 1 - The cause of global warming is related to the change of solar activity.

All the climate processes that take place on the planet depend on the activity of the light source - the Sun. Therefore, even the slightest changes in the activity of the Sun will certainly affect the weather and climate on the Earth. There are cycles of solar activity of 11 years, 22 years, and $80-90$ years (Gleisberg). It is likely that the global warming observed will be associated with another increase in solar activity, which may diminish its action in the future.

Hypothesis 2 - The reason for global warming is related to changing the angle of rotation of the Earth and its orbit. Astronomer Milankovici suggested the idea that cyclical climate change is largely associated with a change in the orbit and angle of inclination of the axis of rotation of the Earth around the Sun. Such orbital changes in the position and motion of the planet cause a change in the radiation balance of the Sun on the Earth and, therefore, its climate. Milankovici, guided by his theory, has accurately calculated the time and extent of the glacial periods of the past of our planet. It seems that the relatively rapid climate change observed now appears as a result of the action of other factors.

Hypothesis 3 - Human activity is the cause of global climate change. The oceans are a huge inertial battery of solar energy, which largely determines the direction and speed of the movement of the warm ocean mass, as well as the air on the Earth, which strongly affects the climate of our planet. At present, the nature of the heat circulation in the water column of the ocean has been little studied. It is known that the average temperature of the ocean waters is $3.5^{\circ} \mathrm{C}$, and the surface of the land is $15^{\circ} \mathrm{C}$, therefore, the exchange of warming between the ocean and the surface layer of the atmosphere can lead to significant climate change. In addition, a large amount of $\mathrm{CO}_{2}$ (about 140 trillion tons, which is 60 times higher than in the atmosphere) and a number of other greenhouse gases are dissolved in ocean waters as a result of natural processes. . These gases can enter the atmosphere, significantly affecting the climate of the Earth.

Hypothesis 4 - volcanic activity. Volcanic activity is a source of sulfuric acid aerosols and a large amount of carbon dioxide, which can significantly affect the climate of the Earth. Large eruptions are initially accompanied by cooling due to sulfuric acid aerosols and soot particles that persist in the atmosphere of the Earth. Subsequently, the CO2 obtained during the eruption causes an increase in the average annual temperature on the Earth. Subsequent long-term decrease of volcanic activity contributes to increasing transparency of the atmosphere and, consequently, to raising temperature on the planet.

Hypothesis 5 - The unknown interaction between the Sun and the planets of the solar system. In the "solar symptom", there are connections between its components. Therefore, it is possible that the relative position of the planets and the Sun will affect the distribution and power of gravitational fields, solar energy, and other types of intergalactic energy. All the connections and interactions between the Sun, the planets, and the Earth have not been sufficiently studied and may have a significant impact on the processes that occur in the atmosphere and the hydrosphere of the Earth.

Hypothesis 6 - Climate change can occur by itself, without external influences and human activities. The Earth is such a large and complex system, with a huge number of structural elements that its global climate characteristics can change significantly without changes in the solar activity and the chemical composition of the atmosphere. Different mathematical models show that over a century, fluctuations of surface air temperature can reach $0.4^{\circ} \mathrm{C}$. As a comparison, we can give the example of a healthy person's body temperature, which varies throughout the day and even hours.

Hypothesis 7 - Man is to blame - the most popular hypothesis nowadays. The high rate of climate change that took place last decades can really be explained by the increasing intensification of the anthropic activity, which has a noticeable effect on the chemical composition of the atmosphere of our planet towards an increase in the content of greenhouse gases. Indeed, an increase in the average air temperature in the lower layers of the atmosphere of the Earth by $0.8^{\circ} \mathrm{C}$ over the past 100 years is a too high rate for natural processes. In the history of the Earth, such changes have taken place over the millennia. The last decades added 
consumption increased by 1.4 million barrels per day above average or by $1.5 \%$. China (680 thousand barrels per day) and the US (500 thousand barrels per day) were the biggest participants in the increase in oil demand [5]. World oil production increased by 2.2 million barrels per day. Almost all net growth was provided by the United States, and the increase in oil production in the United States was a record for any country [15].

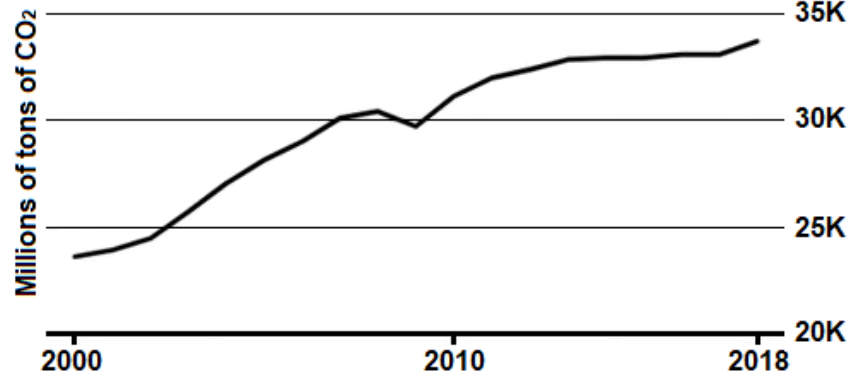

Fig. 3 Dynamics of Growth of CO2 Emissions 2000-2018 [authors' research based on [5]

In recent decades, an increase in atmospheric temperature has been observed faster than ever. To a certain extent, this is due to human activities, which, first of all, warms the atmosphere by burning a huge amount of coal, oil and gas, and there are also natural and anthropogenic factors. Secondly, burning fossil fuels as well as destroying forests leads to the accumulation of carbon dioxide in the atmosphere. In the last 120 years, when humankind used fossil fuels very intensively, the increased gas content in the atmosphere acts as a glass in a greenhouse: $\mathrm{CO}_{2}$ freely passes sunlight to the surface of the Earth, but retains the heat of the surface of the Earth heated by the sun. The rate of emissions has increased since the year 2000. The use of natural gas has covered $40 \%$ of the increase in demand for energy worldwide. The consumption of other types of fuel for energy production has increased faster than the average rate over 10 years. The share of renewable energy sources in global energy production has increased less. Emissions in China, the US and India accounted for more than $2 / 3$ of global energy demand, energy consumption in the US has increased at a rapid pace in 30 years.

Oil. The last century the demand for fossil energy resources increased, thanks to the development of the automotive and chemical industries. In 2018, global oil

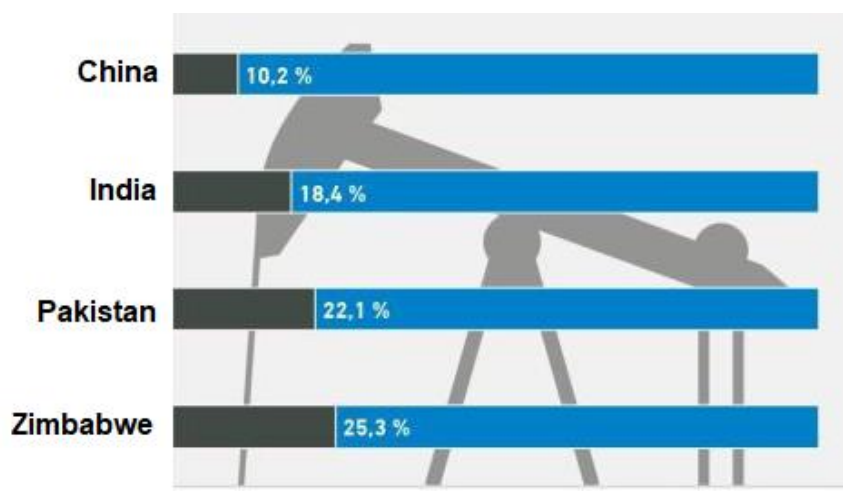

Fig. 4 Oil Consumption in Some Emerging Countries, 2017 [10]

Natural gas. Natural gas consumption has increased by 195 billion $\mathrm{m}^{3}$, or $5.3 \%$. This is one of the highest growth rates since 1984. The increase in gas consumption was mainly provided by the US (78 billion $\mathrm{m}^{3}$ ), with the support of China (43 billion $\mathrm{m}^{3}$ ), Russia $\left(23\right.$ billion $\left.\mathrm{m}^{3}\right)$ and Iran (16 billion $\mathrm{m}^{3}$ ).

There is a strong competition for natural gas suppliers among liquefied gas exporting countries. The main suppliers for Europe are Qatar, Algeria and Nigeria. Today, 18 countries produce and export LPG. In 2017, its deliveries amounted to 323 billion $\mathrm{m}^{3}$ or 230 million tons (in total, that year, approximately 770 billion $\mathrm{m}^{3}$ of gas were exported). Qatar is the undisputable world leader in the LPG market. Australia has been catching on for some time now, which previously played no visible role on the global natural gas market. Malaysia, Indonesia, Algeria and Nigeria also have high liquefaction capabilities.

US occupies the seventh position in the list as for the delivery of LPG. For these reasons, we assume that the

\begin{tabular}{|c|c|c|c|c|}
\hline 1.Iran & 1183,0 & $18 \%$ & 11.Algeria & $159,1(2,4 \%)$ \\
\hline 2.Russia & 1139,6 & $17,3 \%$ & 12.Iraq & $130,5(2,0 \%)$ \\
\hline 3.Qatar & 858,1 & $13 \%$ & 13.Australia & $122,6(1,9 \%)$ \\
\hline 4.Turkmenistan & 617,3 & $9,4 \%$ & 14.Indonesia & $101,2(1,5 \%)$ \\
\hline 5.US & 307,7 & $4,7 \%$ & 15.Canada & $76,7(1,2 \%)$ \\
\hline 6.Saudi Arabia & 297,6 & $4,5 \%$ & 16.Egypt & $65,2(1,0 \%)$ \\
\hline 7.UAE & 215,1 & $3,3 \%$ & 17.Kuwait & $63,0(1,0 \%)$ \\
\hline 8.Venezuela & 201,3 & $3,1 \%$ & 18.Norway & $62,3(0,9 \%)$ \\
\hline 9.China & 189,5 & $2,9 \%$ & 19.Libya & $53,1(0,8 \%)$ \\
\hline 10.Nigeria & 186,0 & $2,8 \%$ & 20.India & $43,3(0,7 \%)$ \\
\hline
\end{tabular}

Fig. 5 Known Natural Gas Reserves, Trillion m3 and \% of World Deposits [19] 


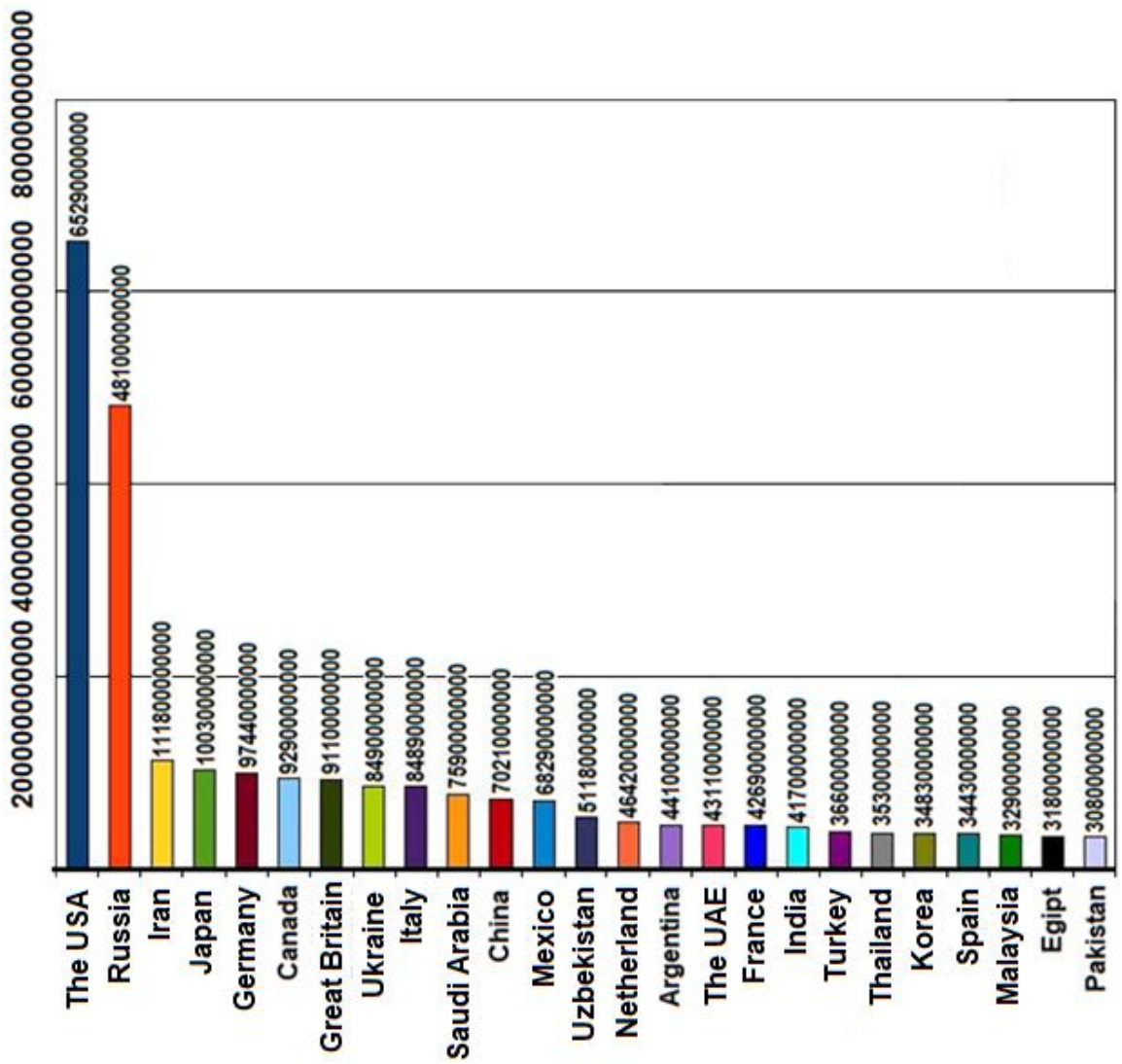

Fig. 6. Natural Gas Consumption. Comparative Analyzes by Countries $[10 ; 11]$

Russia's competitor (Gazprom) can be LPG from Africa and Asia.

Coal. Another source of energy is coal. Coal consumption in 2018 increased by $1.4 \%$, doubling the average for 10 years. India (36 million tons of oil equivalent) and China (16 million tons of oil equivalent) are leaders in coal consumption. OECD demand for coal has dropped to its lowest level since 1975. The share of coal in primary energy production has dropped to $27.2 \%$ - the lowest level in the last 15 years. However, in 2018, global coal production increased by 162 million tons or $4.3 \%$. China ( 82 million tons of oil equivalent) and Indonesia (51 million tons of oil equivalent) had the largest increase in coal production. Both coal consumption and production have increased at the fastest rate over five years due to the need for developing countries to connect millions of homes to a cheap source of electricity.

Wood and forest. The word forest is originated from the Latin word "foris". It is deciphered as a space of trees and shrubs. From the history of humanity, the forest means place of living, shelter, source of energy, oxygen, food, tools of work, and weapons of war. On a global scale, a decrease in the forest surface is harmful to the environment, as it leads to disturbances in the natural balance and the cycle of carbon dioxide, solar radiation and water between the surface of the Earth and the atmosphere. The authors' research has confirmed that in most regions of the world, the disappearance of forests leads to daytime warming and night cooling. Forests cover $31 \%$ of the surface of our planet. According to the authors' estimates, the world currently loses over 9 million hectares of forest per year (equal to the size of
Portugal). Deforestation dos not only affect the climate, increasing the level of carbon dioxide in the atmosphere, but it also has a huge impact on the environment, preventing water recirculation, causing severe flooding, aquifer depletion, soil degradation and extinction of plant and animal species.

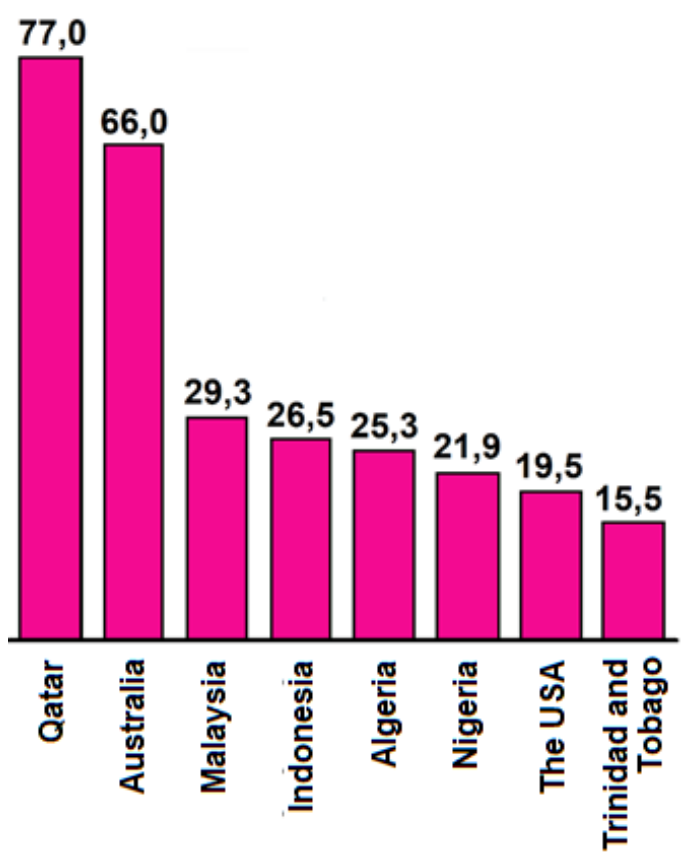

Fig. 7 LPG Production Capacities, million t, 2018 [3] 


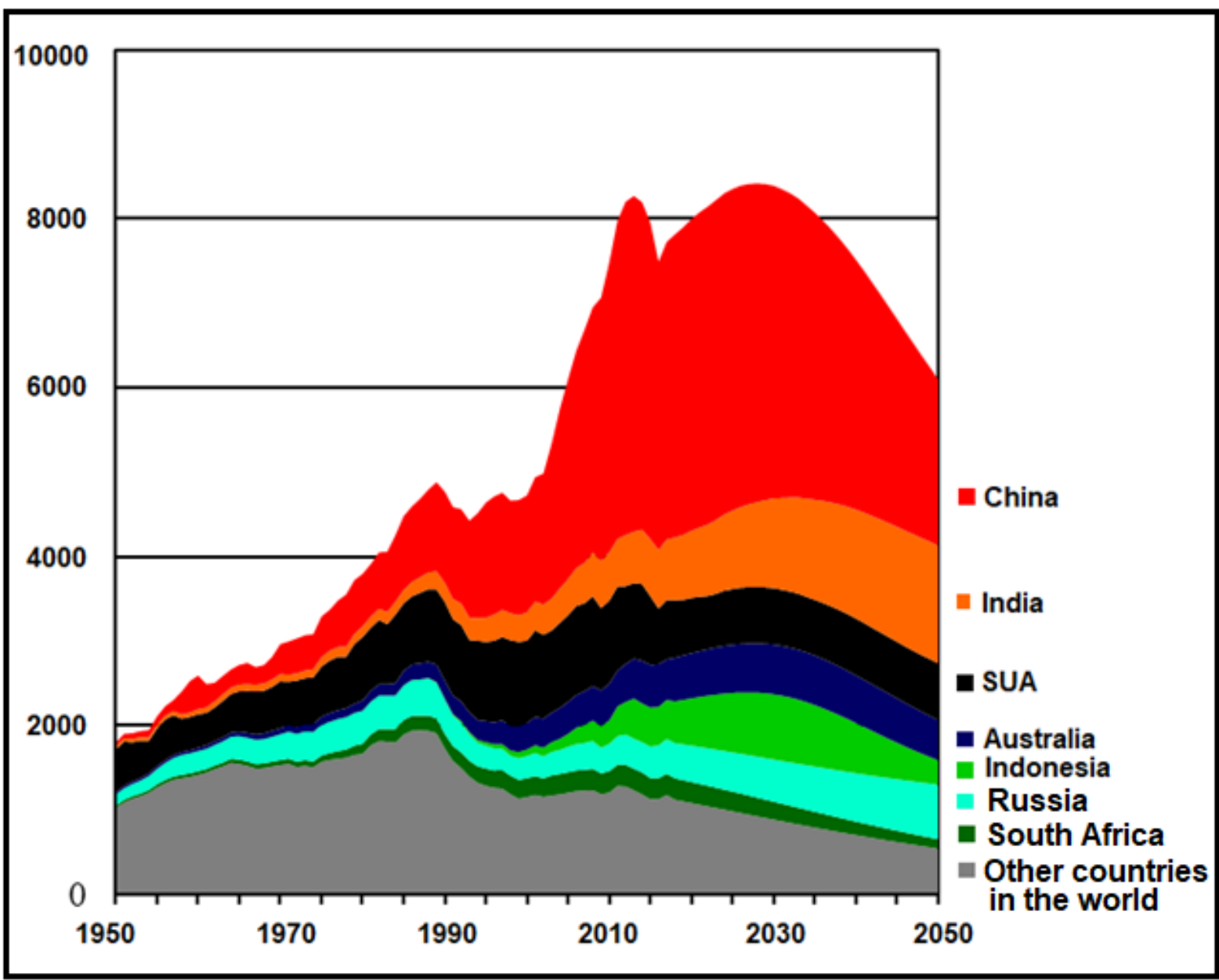

Fig. 8. Worldwide Coal Production and Forecasting by Countries, 1950-2050 [1; 12]

TABLE I. COUNTRIES WITH THE LARGEST FOREST RESOURCES ON THE GLOB [21]

\begin{tabular}{|c|c|c|c|c|c|}
\hline \multirow{3}{*}{ Countries } & \multirow{3}{*}{$\begin{array}{c}\text { Land area } \\
\text { (thousands } \\
\text { ha) }\end{array}$} & \multicolumn{4}{|c|}{ Planted surface } \\
\hline & & \multirow{2}{*}{$\begin{array}{c}\text { (thousands } \\
\text { ha) }\end{array}$} & \multicolumn{2}{|c|}{ in \% } & \multirow{2}{*}{$\begin{array}{c}\text { Per } \\
\text { capita } \\
\text { ha }\end{array}$} \\
\hline & & & $\begin{array}{c}\text { Totally } \\
\text { globally }\end{array}$ & Dry & \\
\hline Russia & 1688851 & 851392 & 22,0 & 50,4 & 5,8 \\
\hline Brazil & 845651 & 543905 & 14,1 & 64,3 & 3,2 \\
\hline Canada & 922097 & 224571 & 6,3 & 26,5 & 7,9 \\
\hline The USA & 915895 & 225993 & 5,8 & 24,7 & 0,8 \\
\hline China & 932743 & 163480 & 4,2 & 17,5 & 0,1 \\
\hline Australia & 768230 & 154539 & 4,0 & 20,1 & 8,3 \\
\hline R.D.Kongo & 226705 & 135207 & 3,5 & 59,6 & 2,7 \\
\hline Indonesia & 181157 & 104986 & 2,7 & 58,0 & 0,5 \\
\hline $\begin{array}{c}\text { Totally } \\
\text { globally }\end{array}$ & 13063900 & 3869455 & 100,0 & 29,6 & 0,65 \\
\hline
\end{tabular}

In the context of climate change, the most important thing in forests is not the reduction of $\mathrm{CO}_{2}$ in the air, but that they are huge reservoirs of stored carbon. If forests are cleared, most of this carbon is returned to the atmosphere, increasing the $\mathrm{CO}_{2}$ content accumulated.

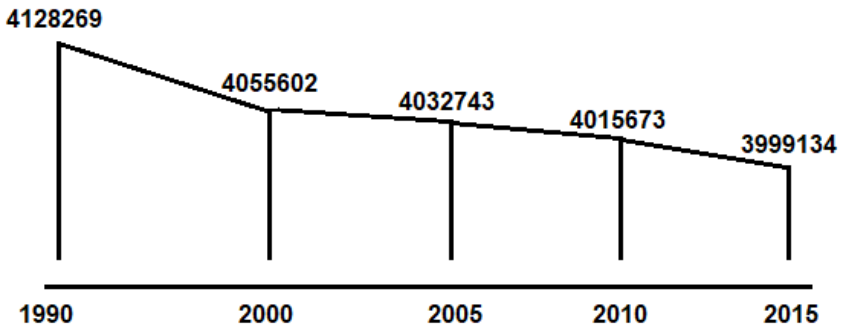

Fig, 9 Dynamics of Diminishing the Surface of Forests on the Glob, thousands ha [20]

Rainforests contain more than 210 gig tons of carbon, and deforestation accounts for about $15 \%$ of greenhouse gas emissions. On a sunny day, one hectare of forest absorbs $120-280 \mathrm{~kg}$ of carbon dioxide from the air and releases 180$200 \mathrm{~kg}$ of oxygen.

Renewable energy. In the modern concept of sustainable development strategy, the importance is given to the problems of energy sources for both countries and regions. As traditional energy sources are limited and expensive, the hope of the majority is for renewable sources, which play an important role in the energy supply of industrial enterprises, agricultural complexes, different types of transport and numerous household consumers [24]. It is considered that renewable energy should be based on a variety of natural resources, which, unlike the traditional ones, such as oil and gas, can be considered inexhaustible (sunlight, wind, river flows, sea tides, geothermal sources, etc.). At the same time, 


\begin{tabular}{|c|c|c|c|c|c|}
\hline $\begin{array}{c}\text { Solar } \\
\text { energy }\end{array}$ & $\begin{array}{c}\text { Wind } \\
\text { energy }\end{array}$ & $\begin{array}{c}\text { Ocean } \\
\text { energy }\end{array}$ & $\begin{array}{c}\text { Hydro- } \\
\text { electrical } \\
\text { energy }\end{array}$ & $\begin{array}{c}\text { Geothermal } \\
\text { energy }\end{array}$ & Bioenergy \\
\hline $\begin{array}{c}\text { Source: } \\
\text { Sun }\end{array}$ & $\begin{array}{c}\text { Source: } \\
\text { Wind }\end{array}$ & $\begin{array}{c}\text { Source: } \\
\text { Tidal waves }\end{array}$ & $\begin{array}{c}\text { Source: } \\
\text { Water }\end{array}$ & $\begin{array}{c}\text { Source: } \\
\text { Land }\end{array}$ & $\begin{array}{c}\text { Source: } \\
\text { Biomass, } \\
\text { waste }\end{array}$ \\
\hline $\begin{array}{c}\text { Technologies: } \\
\text { Photovoltaic } \\
\text { installations, } \\
\text { solar } \\
\text { thermal }\end{array}$ & $\begin{array}{c}\text { Technologies: } \\
\text { Wind } \\
\text { turbines }\end{array}$ & $\begin{array}{c}\text { Technologies: } \\
\text { Dams, tidal } \\
\text { dams }\end{array}$ & $\begin{array}{c}\text { Technologies: } \\
\text { Hydroelectric } \\
\text { power } \\
\text { stations }\end{array}$ & $\begin{array}{c}\text { Technologies: } \\
\text { Geothermal } \\
\text { installations } \\
\text { and heat } \\
\text { pumps }\end{array}$ & $\begin{array}{c}\text { Technologies: } \\
\text { Biomass } \\
\text { burning, } \\
\text { biogas } \\
\text { plants, } \\
\text { biofuels }\end{array}$ \\
\hline $\begin{array}{c}\text { Applications: } \\
\text { Electricity, } \\
\text { heating and } \\
\text { cooling }\end{array}$ & $\begin{array}{c}\text { Applications: } \\
\text { Electricity }\end{array}$ & $\begin{array}{c}\text { Applications: } \\
\text { Electricity }\end{array}$ & $\begin{array}{c}\text { Applications: } \\
\text { Electricity }\end{array}$ & $\begin{array}{c}\text { Applications: } \\
\text { Electricity, } \\
\text { heating and } \\
\text { cooling }\end{array}$ & $\begin{array}{c}\text { Applications: } \\
\text { Electricity, } \\
\text { heating, } \\
\text { cooling and } \\
\text { transport }\end{array}$ \\
\hline
\end{tabular}

Fig. 10. The Main Sources of Non-traditional Renewable Energy [17]

different biomass of natural and anthropogenic origin, which is made up of specially cultivated plants for energy production, is considered as special sources of renewable energy and is also part of household waste [8]. Consequently, some more significant effects are expected for sustainable development from the formation and active use of renewable energy [23]. First, it is obvious that the use of inexhaustible energy sources will have to reduce the dependence on fossil carbon raw materials for economies in different countries and regions, especially for those who are forced to buy this raw material due to the geological characteristics. Second, it is assumed that the transition (at least in part) to renewable energy will significantly reduce greenhouse gas emissions and therefore have a positive (stabilizing) effect on the environment and will provide a powerful incentive for the development of new technologies. Third, the disposal of fabricated waste, which has already begun to be used as renewable energy sources, should naturally protect the environment from serious threats to pollutants. Renewable energy consumption increased by $15 \%$ in 2018 , which is close to a record increase from a year earlier. China leads the generation of renewable energy, generating more than the world's most developed countries in the OECD. The transition to a sustainable economy is a global task of the entire world community, of all states, regardless of the level of development, of the shape of the economic system.

In the favorable 3D scenario for Moldova and most countries (diversification, decentralization, disintermediation), the national economy is expected to develop constantly (including thanks to rising oil prices), to diversify its structure, to have a favorable political environment, to improve the investment climate and to ensure the access of energy companies for financial resources and new technologies on the international market, which will ensure the consistent technological development of renewable energy $[2 ; 3 ; 18]$.

The increase in the production of wind, solar, geothermal, biomass and waste incineration has constituted about one third of the increase in total electricity production or in the same way as coal burning. However, they do not cover global needs. The demand for primary energy in 2018 grew at the fastest pace in this decade, even though it weakened global economic growth. China, India and the United States account for two thirds of the $2.9 \%$ increase in energy consumption.

The rate of heating will double. All over the world there is an urgent need to curb the global rise in temperature, which has increased by 1 degree Celsius since the beginning of the industrial revolution, and by the end of the century it should at least double, according to the authors' research. This has been the fastest climate change since the end of the last ice age 10 thousand years ago. In a time when society is concerned about climate change and the need for action, energy demand and carbon emissions are growing at the fastest rate in recent years. Much of the increase in record demand for electricity is due to changing weather conditions. The number of days that were either unusually hot or cold increased, which increased the use of energy for heating and cooling rooms. Consequently, global $\mathrm{CO}_{2}$ emissions increased in 2018 for the third year in a row, and this trend is likely to continue. In 2015 , nearly 200 countries pledged to take measures to limit global warming to below 2 degrees under the Paris Climate Change Agreement. Their goal was to combat natural disasters - floods, droughts, which are supposed to occur more often with continuous climate change. However, their efforts are still insufficient [5].

Extreme weather phenomena, unstable climatic conditions that affect nutrition and water supply, new 
outbreaks of infectious diseases caused by changes in ecosystems, there are diseases caused by global warming and pose a health hazard. Climate and weather already have a major impact on health: more people die during periods of extreme heat and during natural disasters, such as floods, which pose a threat to communicable diseases, such as malaria [1].

Despite the fact that the total growth of renewable energy sources will be for the period 2015 - 2035, over $7000 \%$, Russia's domestic consumption is projected at $1 \%$, while in the BRICS countries, the average consumption of renewable sources will approach $11 \%$. Natural gas will remain the main fuel for electricity production, falling slightly from $55 \%$ in 2015 to $54 \%$. The growth of nuclear energy production will be from $15 \%$ (today) to $18 \%$ by 2035 , hydropower - from $13 \%$ to $15 \%$, and the share of coal from $15 \%$ will decrease to $10 \%$. The growth of renewable sources will be from $0 \%$ (today) to $3 \%$ by the end of the forecast period. Russia's share in global energy production will drop slightly - from $10 \%$ in 2015 to $9 \%$ in 2035.

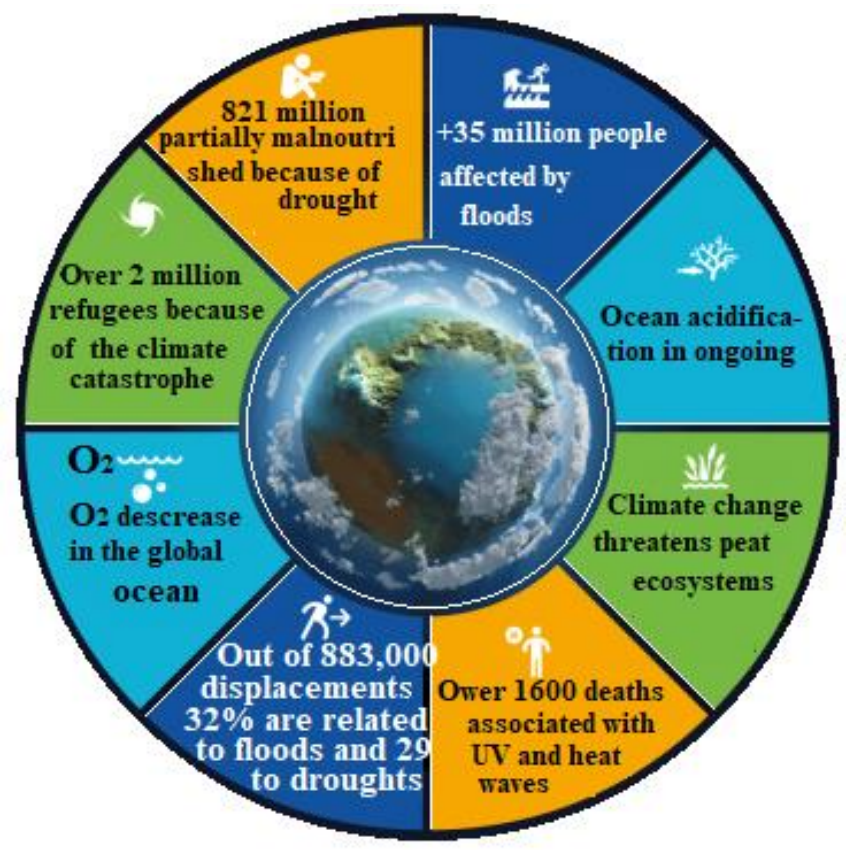

Fig, 11 Climate Risks, Extreme Events and Related Impacts [4]

Physical manifestations of climate change mitigate the social and economic impact of the population. Record levels of greenhouse gases cause global temperatures to rise to alarming levels, according to a report published by the World Meteorological Organization [4]. The 25th edition of the WMO Declaration on the state of the global climate highlights the record rise of the sea level and unusually high temperatures observed over the last five years on the surface of the Earth, the oceans. This warming trend has not ceased since the beginning of this century and, on the contrary, it will continue.

Over the past 50 years, because of human activities, in particular the burning of fossil fuels, large quantities of carbon dioxide and other greenhouse gases have been released into the atmosphere, affecting the global climate. The content of carbon dioxide in the atmosphere increased by more than $30 \%$ compared to its level before the industrial revolution. From the tropics to the Arctic, climate and weather have strong direct and indirect effects on human life.
There are extreme weather events such as heavy rain, floods and natural disasters. Intense short-term weather fluctuations can also affect health, causing thermal stress (hyperthermia) or excessive cooling (hypothermia), which can increase mortality rates from heart and respiratory diseases. Recent studies indicate that the high temperatures in Western Europe in the summer of 2018-2019 have led to a marked increase in mortality - the number of deaths recorded in this period is 77,000 more than in the equivalent periods of previous years.

By 2018, most natural hazards, affecting nearly 62 million people, were linked to weather and climate. As in the past, the floods were the ones that affected most people more than 35 million - according to an analysis of 281 phenomena listed by The Centre for Research on the Epidemiology of Disasters (CRED) and the United Nations Office for Disaster Prevention. Estimating economic losses will motivate Governments to take more measures to meet the recommendations of the Sendai Framework for Disaster Risk Reduction. They aim to substantially reduce catastrophic losses by 2030 [12].

Pollen and other allergic substances will see growth at high air temperatures. This can cause asthma, which affects about 300 million people worldwide. Actual increases in seasonal temperatures step up the spread of this problem. Rising sea level, another result of global warming, increases the risk of coastal flooding and can lead to population displacement in other areas. Currently, more than $60 \%$ of the world population lives $60 \mathrm{~km}$ offshore. Flooding can directly lead to injury and death and increase the risk of contracting waterborne and communicable diseases. Displacement can increase the stress and potential risk of military, political, social, economic conflicts. Increasing changes in precipitation may affect freshwater reserves. Worldwide, four out of ten people already have water problems. Lack of water and poor water quality can pose a danger to hygiene and health. This increases the risk of developing diarrhea, about 2.2 million people die of it each year, as well as trachoma (an eye infection that can lead to blindness) and other diseases. The lack of potable water compels people to bring water away and store it in homes. This increases the risk of pollution of the water stored in the home, which can lead to a disease. Climate conditions affect the population with waterborne diseases such as mosquitoes. Climate sensitive diseases are among the deadliest diseases in the world. In 2004, only diarrhea, malaria and protein deficiency caused over 3 million deaths worldwide, of which more than a third took place in Africa. Millions of people die each year from malnutrition, both from the nutritional deficiencies needed to maintain their lives and from their vulnerability to infectious diseases such as malaria, diarrhea and respiratory diseases. Due to rising temperatures on our planet and more and more changes in rainfall patterns in many developing tropical areas, where food security is already poor, yields will fall further.

Measures to reduce greenhouse gas emissions or limit health effects through climate change may have other health benefits. For example, encouraging the safe use of public vehicles and active driving - - cycling or riding as an alternative to using personal cars - - can reduce carbon dioxide emissions and improve public health. This cannot only help to reduce road accidents, but also to lower air pollution and the associated incidence of respiratory and 
cardiovascular diseases. Enhanced levels of physical activity may also contribute to lower overall mortality rates.

An assessment of the health effects of climate change can only be approximate. However, according to a WHO estimate, that only takes into consideration a number of potential health effects and assuming continued economic growth and health progress, it concluded that climate change is expected to cause about 250,000 additional deaths by 2030. By 2050, 38,000 people will die from the effects of heat on the elderly, 48,000 from diarrhea, 60,000 from malaria and 95,000 from child malnutrition [6].

Climate change also touches upon the issue of food safety. Warming leads to the growth of bacterial flora in food. At an ambient temperature above $5^{\circ} \mathrm{C}$, each increase in the average weekly temperature by one degree causes an increase in the incidence of salmonella by $5-10 \%$. The hot weather contributes to the more frequent failure of refrigeration equipment, to the reproduction of flies and other pests.

An exacerbated water deficit (water stress) is expected in Central and Eastern Europe and Central Asia. By 2080, the number of populations suffering from water shortage will grow by 16-44 million people. The decrease of the watercourses during the summer will be up to $80 \%$, which will lead to a lack of fresh water and an increased risk of pollution. In addition, the condition of the coastal waters is at peril, creating a risk of infection during sea bathing and the consumption of seafood. Access to safe water and sewage, which is already uneven in the region, may be aggravated.

\section{CONCLUSION}

In recent decades, the climate on the Earth has changed radically: some countries suffer from abnormal heat, others from harsh winters and snow, unusual for these places. Environmentalists are discussing global climate change, including an increase in average annual temperature, causing melting of glaciers and rising global ocean levels. The negative impact of harmful components on flora and fauna, public health, objects and structures is not limited to the territory adjacent to the sources of pollutant emissions, but extends to thousands of kilometers. Therefore, at present, the pollution of the environment is a global challenge and the costs of its protection have become proportional to the extent of the environmental damage. The problem of ensuring energy efficiency and environmental safety of energy installations is multi-faceted (design, operation, examination, audit, forecast, monitoring, etc.) and is multi-evaluated. This is due to the need to determine the level of use of fuel and energy resources, the technical status of the equipment of the energy installations, with the use of environmental measures, etc. The complexity of solving this problem is due to a wide range of parameters, factors and indicators that determine the danger to the environment. The originality of the research lies in the determination of the synergetic aspects of the jointly realized efforts in achieving the global problems. There was established the need to overcome the antagonisms in the social-personal relations, which are the source of the contradictions in the human-society-nature system, which leads to a crisis of the modern man and the exacerbation of the whole spectrum of global problems. The authors' research has shown that innovations, which should improve the state of the environment, human well-being and comfort, but most often the personal, corporate or group interests of people, stop or slow down the problem solving.

\section{REFERENCES}

[1] 10 facts about climate change and health [Electronic source]. Available at: https://www.who.int/features/factfiles/climate_change (Accessed: 15.09.2019).

[2] Alternative energy [Electronic source]. Available at: http://www.tadviser.ru/index.php/ (Accessed: 15.09.2019).

[3] Berlin to Shell: Remove old oil platforms in North Sea, Shell [Electronic source]. Available at: https://www.dw.com/en/berlin-toshell-remove-old-oil-platforms-in-north-sea/a-50862566 (Accessed: 15.09.2019).

[4] État du climat en 2018 - Les conséquences du changement climatique s'intensifient [Electronic source]. Available at: https://public.wmo.int/fr/medias/communiqu\%C3\%A9s-depresse/\%C3\%A9tat-du-climat-en-2018-\%E2\%80\%93-lescons\% $3 \%$ A9quences-du-changement-climatique-s (Accessed: 15.09.2019).

[5] Global warming will double [Electronic source]. Available at: https://www.vestifinance.ru/articles/120712 (Accessed: 15.09.2019).

[6] A. Gribincea and V. Bîrdan, "Epuraş Ovidiu Problema globală substituirea carburanţilor tradiţionali," In: Economie şi sociologie, no. 23, 2011, pp. 47-57.

[7] M. Hulme, "Why We Disagree About Climate Change, Understanding Controversy, Inaction and Opportunity," Cambridge University Press, 2009.

[8] U. C. Kalluri and M. Keller, "Bioenergy research: a new paradigm in multidisciplinary research," Journal of The Royal Society Interface, no. $7, \quad 2010, \quad$ pp. 1391-1401. DOI: https://doi.org/10.1098/rsif.2009.0564.

[9] S. Kuper, "Squabbling while the world burns," In: Financial Times, 25, November 2011.

[10] Raport WTO, 2017 [Electronic source]. Available at: https://www.wto.org/english/res_e/booksp_e/anrep_e/anrep17_e.pdf (Accessed: 15.09.2019).

[11] Raportul ONU, Departamentul economie şi dezvoltare social [Electronic source]. Available at: http://www.bit.ly/wespreport (Accessed: 15.09.2019).

[12] Reducerea-dizastrelor [Electronic source]. Available at: http://md.one.un.org/content/unct/moldova/ro/home/presscenter/secr etary-general-messages/mesaj-de-ziua-internaional-pentrureducerea-dizastrelor.html (Accessed: 15.09.2019).

[13] D. Sarewitz, "The Trouble With Climate Science: More research makes the controversy worse," Slate, 10, März 2010.

[14] Special Report on Renewable Energy [Electronic source]. Available at: https://op.Europa.eu/webpub/eca/special-reports/renevableenergy-5-2018/ro/ (Accessed: 15.09.2019).

[14] The main countries and sectors of the economy - oil consumers [Electronic source]. Available at: https://helpiks.org/1-103566.html (Accessed: 15.09.2019).

[15] WHO. Quantitative risk assessment of the effects of climate change on selected causes of death, 2030s and 2050s. Geneva: World Health Organization, 2014.

[16] Why forests play a key role in preserving climate, water, health and human life [Electronic source]. Available at: https://www.vsemirnyjbank.org/ru/news/feature/2016/03/18/whyforests-are-key-to-climate-water-health-and-livelihoods (Accessed: 15.09.2019).

[17] Wind power: yesterday, today, tomorrow [Electronic source]. Available at: https://alternativenergy.ru/vetroenergetika/66vetrogeneratory-bashennogo-tipa.html.

[18] World gas market - on the map and in graphs [Electronic source]. Available at: http://oilgascom.com/mirovoj-gazovyj-rynok-na-kartei-v-grafikax-bp-magazine/ (Accessed: 15.09.2019).

[19] W. J. Ripple, C. Wolf, M. Galetti, T. M. Newsome, M. Alamgir, E. Crist, M. I. Mahmoud, and W. F. Laurance, "World Scientists' Warning to Humanity: A Second Notice," BioScience, vol. 67, iss. 12, 1 December 2017, pp. 1026-1028.

[1] [20] A. Gribincha, K. Stroe, and O.Epurash, "Viitorul pieței carburanţilor," În: Conferinţă ştiințifică internațională, Problemele 
economice ale dezvoltării europene, Chişinău: ULIM, 25 martie 2011, pp. 23-33.

[2] [21] V. V. Kovalev, O. Kovalev, and V. E. Nenno, "Povyshenie energeticheskih harakteristik biogaza," In: revista Intellectus, 2019, no. 1, pp.143-151.

[3] [22] Mezhdunarodnoe agentstvo po vozobnovlyaemym istochnikam energii, International Renewable Energy Agency, IRENA [Electronic source]. Available at: http://resourceirena.irena.org/ (Accessed: 15.09.2019).
[23] Prinyatie mer po zashchite zdorov'ya naseleniya Evropy ot izmenenij klimata [Electronic source]. Available at: http://www.euro.who.int/_data/assets/pdf_file/0011/95834/

fs_4_Apr_08r.pdf?ua=1 (Accessed: 15.09.2019).

[24] 10 țări cu cea mai mare suprafață forestieră [Electronic source]. Available at: http://www.priroda.ru/reviews/detail.php?ID=6609 (Accessed: 15.09.2019). 